\title{
Co-Production Related To Business Counselling in the Microfinance Sector as a Demonstration of Social Cooperation: An Interpersonal Relationship Approach
}

https://doi.org/10.21272/sec.4(2).56-66.2020.

\author{
Ruwan Abeysekera, ORCID: https://orcid.org/0000-0002-2858-6483
}

$\mathrm{PhD}$, Senior Lecturer, Department of Finance, University of Kelaniya, Sri Lanka

\begin{abstract}
Microfinance Institutions (MFIs) provide services such as microcredit, savings, insurance and Business Development Services (BDS) to low income people in order to start new businesses and expand existing businesses. MFIs cater to micro enterprises. A microenterprise is defined as an owner-managed business that has fewer than 10 employees. The studies show that micro enterprises not only need micro credit, but also BDS in order to grow their businesses. This study focuses on BDS. BDS are non-financial services such as management training, vocational training skills, marketing assistance and technology access provided to owner managers by MFIs. MFIs could provide BDS to owner managers/clients using business counselling. A good relationship between the counsellor and the client can be considered a defining feature of any successful counselling intervention. This interpersonal relationship enhances co-production of BDS in counselling. Therein, the objectives of this study are; to identify the factors that enhance the interpersonal relationship between the counsellor and the client in microfinance settings that result in enhanced co-production, to identify how interpersonal relationships enhance co-production, and to understand how organisational factors affect interpersonal relationships. The multiple case study method was used to conduct the study and six (6) Sri Lankan Microfinance Institutions (MFIs) were chosen as cases and data was collected by holding in-depth interviews. Findings show that factors such as the expertise of the counsellors, social interaction, similar attitudes, intensity of contacts, and power distance influence the relationship between the counsellors and the clients. As a result of the enhanced interpersonal relationships between counsellor and client, parties exchange personal and communal favours thereby further enhancing co-production as well as improving the provision of information by clients. The findings further reveal that interpersonal relationships could be affected by the organisational factors such as the type of MFI and type of linkages. Therefore, the findings of this study will enable MFIs to improve the counselling intervention and will further contribute to the microfinance knowledge and practice domains.
\end{abstract}

Keywords: interpersonal relationship, co-production, counselling, microfinance, business development services (BDS).

\section{JEL Classification: M10.}

This work is licensed under a Creative Commons Attribution 4.0 International License.

Cite as: Abeysekera, R. (2020). Co-Production Related To Business Counselling in the Microfinance Sector as a Demonstration of Social Cooperation: An Interpersonal Relationship Approach. SocioEconomic Challenges, 4(2), 56-66. https://doi.org/10.21272/sec.4(2).56-66.2020.

(C) The Author, 2020. This article is published with open access at Sumy State University.

\section{Introduction}

Microfinance is the provision of small unsecured loans (microcredit) and other services such as insurance, savings, business development services (BDS) to individuals or groups to start new businesses or expand existing businesses (Khavul, 2010; ADB, 1997). Microfinance Institutions (MFIs) provide these services to low income people. It is believed that there are 2.8 billion people living in the world whose income is less than $\$ 2$ a day (World Bank, 2014; Easterly, 2006, p.165). MFIs target this segment of population. MFIs use innovative techniques such as group lending, group liability, increasing loan sizes and pre-loan savings 
requirement to provide its services that cannot be provided by the traditional banking system (Cull et al., 2018; CGAP, 2011; Khavul, 2010; ADB, 1997).

Sri Lanka has an established microfinance sector whose roots can be traced back to 1900s (GTZProMis, 2010a; Tilakaratne et al., 2005). There are different types of MFIs operating in Sri Lanka that represent government, NGOs, cooperatives, banks and non-banks (GTZProMis, 2010a). These MFIs have more than 10,000 branches that cover the whole island. The microfinance sector in Sri Lanka is getting commercialised and thus, banks and non-banks are venturing in to this sector (Attapattu and De Silva, 2009). The government of Sri Lanka is keen to develop the microfinance sector in Sri Lanka and as a result it has taken ownership of major MFIs, providing funding and fine-tuning the regulations of microfinance (NEDA, 2013; Tilakaratne et al., 2009).

Studies show that not only credit, but also non-financial services are important for entrepreneurs to develop their businesses. Non-financial services provided by MFIs are called business development services (BDS) (Fisher and Sriram, 2002; Gulli and Berger, 1999; Wright, 1999; Mosley and Hulme, 1998; Johnson and Rogaly, 1997; Rogaly, 1996; Hulme and Mosley, 1996) BDS include services such as assistance in loan application, business registration, production, marketing, input supplies, financial literacy etc., BDS improve owner managers' productivity, boost their competitiveness, enhance service delivery, market access and product design (Mulamula, 2018; Sievers and Vandenberg, 2007). The counsellors attached to MFIs provide BDS to clients. In effect, counsellors and clients have to maintain good interpersonal relationships in order to provide BDS effectively. Studies show that interpersonal relationships between the customer contact staff and customers enhance the co-production between parties ( Weaver et al., 2019; Guo and NG, 2010; Etgar, 2008; Bettencourt et al., 2002). Co-production refers to the joint production situations where the customer contact staff of the firm and the customer interact and participate in the production (Meuter and Bitner, 1998). Thus, co-production enhanced by interpersonal relationships between the counsellors and the clients are key to the successful counselling intervention in a microfinance setting. Thus far, no study has been conducted on the importance of interpersonal relationships in coproduction in business development services in microfinance setting. Therefore, the present study fills this gap by focusing on the following research questions: what are the factors that affect the interpersonal relationships between the counsellors and the clients in co-production?; how do interpersonal relationships enhance the co-production in BDS?; and how do organisational factors affect interpersonal relationships? The remainder of the article is organised as follows. Firstly, a review of existing literature related to the study is presented, and is followed by an explanation of the research methodology used herewith. Then the findings of the study are presented. Finally, the conclusions, discussion of findings and implications are discussed.

\section{Literature Review}

\subsection{Counselling}

Counsellors provide advice to aspiring, embryonic and established businesses to manage the problems that they confront and exploit growth opportunities (Johnson, 1991). When providing counselling, the counsellors build relationships with the clients to assist the clients to identify and achieve their personal, entrepreneurial, and business goals (Canadian APEC, IBIZ, 2015; Johnson, 1991). Studies show that owner managers of small firms are able to enhance their business knowledge, improve sales, market share, growth and survival rates due to the counselling they receive. (Cumming and Fischer, 2012; Klinger and Schündeln, 2011; Schayek and Dvir, 2009; Rice, 2002; Chrisman and McMullan, 2000).

In microfinance settings, counsellors provide counselling to clients (i.e. owner managers of microenterprises), free of charge and provided at community centres, client's home or business premise, at an MFI branch office or even on the road (Abeysekera, 2016). For an effective counselling intervention, the counsellors and the clients have to collaborate with each other and thus, co-production between the two parties is vital.

\subsection{Co-production}

The concept of co-production was introduced in a workshop on political theory and policy analysis held at Indian University, US in 1973. Initially, the concept was related to the citizen or client involvement in production and it became popular among scholars of public administration in the US in 1970 and 1980s (Parks et al., 1981). There are many definitions given for co-production. For this study, co-production refers to the joint production situations where the company's customer contact staff and the customer interact and participate in the service production (Meuter and Bitner, 1998). 
Recent studies on value creation and service-dominant logic of marketing has fuelled the idea of co-production (Prahalad and Ramaswamy, 2004a, 2004b, 2002, 2000; Vargo and Lusch, 2006, 2004) Until recently, it was believed that the customer value creation is dependent on the product (Goods dominant logic, G-D). However, Vargo and Luch (2004) assert that customer value creation relies on the service provision (Service dominant, S-D) rather than in the finished good. According to S-D logic, value creation is done by the personalised interactions between the firm and the customers. These interactions are mutually beneficial and reciprocal to both parties. Thus, interpersonal relationships between the firm's staff and customers are important in value creation and thereby, result in enhanced co-production ( Guo and NG, 2010). It is assumed that interpersonal relationships between the counsellors of MFIs and the clients enhance the co-production in BDS and thus, bring both parties benefits such as, MFI having a better loan repayment rate and the owner managers having better sales and profits.

\subsection{Interpersonal relationship between client-contact staff and clients in co-production}

The existent literature shows that interpersonal relationships between the client and client-contact staff enhances co-production (Guo and NG, 2010; Etgar, 2008). According to marketing and service literature, interpersonal relationship is a construct based on the trust and satisfaction (Crosby and Stephens, 1987; Swan et al., 1985). Schayek and Dvir (2009) find that the relationship between a client in a small firm and a business counsellor increases due to trust and emotional closeness between the parties. Further, the relationship enhances the performance of the small firm. The literature on marketing reveals that the client and clientcontact staff could improve interpersonal relationships due to a number of factors such as similarities, expertise, and intensity of contact (Bove and Johnson, 2000; Lean et al., 1999; Crosby et al., 1990; Tan, 1981; Taylor and Woodside, 1981; Busch and Wilson, 1976; Byrne, 1969).

Etgar (2008) asserts that interpersonal relationships (i.e. interaction) between the service provider and the customer improves the co-production. Further, Bettencourt et al. (2002) study on Knowledge Intensive Business firms (KIBS) shows that relationship between the service provider and the client boosts the coproduction. Moreover, Guo and NG's (2010) study on equipment based services also found that interpersonal relationships between managers in two firms enhance interpersonal relationships resulting in co-production.

Only a few studies have looked at the importance of interpersonal relationships in co-production and further, there has not been any study done on this in microfinance settings. Thus, the present study attempts to fill this gap by focusing on interpersonal relationships between the counsellors of MFIs and the owner managers of microenterprises that enhance the co-production in BDS. In this respect, it is assumed that organisational factors such as type of MFI and type of linkage could have a bearing on the interpersonal relationships between the counsellors and owner managers thus the co-production.

\subsection{Organisational factors affecting the co-production in counsellor-client interpersonal relationships}

\section{Types of MFIs}

There are four types of MFIs (Jansson et al., 2004)

- Non-profit MFIs (e.g. NGOs)

- Bank MFIs

- Non-bank MFIs

- Cooperative/credit union MFIs

The goals of the MFI, the nature of investors, and market segments may vary depending on the type of the MFI. For example, cooperative and NGO MFIs may want to achieve social goals and are funded by the members. Further, these MFIs cater to poorer clients (Galema et al., 2012; Maes and Foose, 2006). It is assumed that the type of MFI would influence the relationship between the counsellors and the clients.

\section{Type of Linkages}

MFIs use three types of linkages to provide credit and BDS to its clients (Dunford, 2001). These types are given below.

Unified: credit and BDS are provided by the same people.

$>$ Parallel: MFI has two departments to provide credit and BDS. Thus, different people provide these services. 
Linked (or partner): two distinct institutions: two different institutions offer credit and BDS. Each institution refers its clients to the other institution for services.

The type of linkage could also affect the interpersonal relationships.

Co-production literature hardly looks at how the context including the organisational factors affect the coproduction. Hence by focusing on organisational factors this study attempts to fill this lacuna as well.

\section{Research methodology}

Examining the interpersonal relationships between the counsellors of MFIs and the owner managers of microenterprises is a contemporary phenomenon that has not heretofore been explored in depth by the researchers. Hence, the case study method is appropriate for this study as it helps explore a phenomenon in depth(Yin,2009). Analysis of multiple case studies instead of a single case study was chosen as the research strategy for this study as it enhances the theoretical generalisation. Six cases (i.e. MFIs) were selected for this study and this number coincides with 4-6 cases suggested by Eisenhard (1989) for a multiple case study method. The unit of analysis for this study was dyadic relationships between the counsellors of MFIs and owner managers of microenterprises.

The cases and respondents were selected using purposive sampling method. Further, MFI type and type of linkage were used to select six cases. In addition, one counsellor and two owner managers were chosen from each MFI for the data collection.

The details of the MFIs selected for the study are given below in the Table 1.

Table 1. Details of MFIs chosen for the study

\begin{tabular}{|c|c|c|}
\hline MFIs & Type of MFI & Type of Linkage \\
\hline MFI-1 & Private Non-bank & Parallel \\
\hline MFI-2 & Cooperative /credit union & Parallel \\
\hline MFI-3 & Private Bank & Unified \\
\hline MFI-4 & Government, Non-Bank & Unified \\
\hline MFI-5 & NGO & Unified \\
\hline MFI6 & Government & \\
\hline
\end{tabular}

Source: compiled by the author.

A pilot study was conducted in order to refine the semi-structured questionnaire before the data collection commenced. For the purpose of data collection, 18 in-depth interviews (i.e. 3 from each case) were held, spending around 45-90 minutes per interview. Informed consent was taken from each case and the respondent to ensure adherence to ethical considerations. Thematic analysis was used to analyse the data based on the interview transcripts as well as pattern matching and cross-case synthesis were used as the main analytical techniques(Yin, 2009).

Reliability and validity were looked at in this study. Reliability was achieved by following the case study protocol (Yin,2009). By using a number of data sources such as in-depth interviews, observations and company records, construct validity was achieved. Using pattern matching internal validity was attained as it helps see relationships. External validity which is is concerned with the generalisation, was realised as the study used multiple cases. Though this qualitative study does not look at generalisation, to a certain extent, the findings could be generalised given the selection of multiple cases.

The thematic analysis was carried out focusing on the main research questions: what are the factors that affect the interpersonal relationships between the counsellors and the owner managers in co-production?; how do interpersonal relationships enhance the co-production in BDS?; and how do organisational factors affect interpersonal relationships?

\section{Findings}

The findings of the study are summarized in the table below. 
Table 2. Findings of the study

\begin{tabular}{|l|l|}
\hline \multicolumn{1}{|c|}{ Research Question } & \multicolumn{1}{|c|}{ The findings } \\
\hline $\begin{array}{l}\text { What are the factors that affect the interpersonal relationships } \\
\text { between the counsellors and the owner managers in co- } \\
\text { production? }\end{array}$ & $\begin{array}{l}\text { Expertise of the counsellor, similarities, intensity of contacts, } \\
\text { power distance and debt collection role of the counsellor. }\end{array}$ \\
\hline $\begin{array}{l}\text { How do interpersonal relationships enhance the co-production in } \\
\text { BDS? }\end{array}$ & Personal favours, communal favours, information provision. \\
\hline $\begin{array}{l}\text { How do organisational factors affect interpersonal relationships } \\
\text { between the counsellors and the owner managers? }\end{array}$ & $\begin{array}{l}\text { Type of MFI and type of Linkage affect the interpersonal } \\
\text { relationships. }\end{array}$ \\
\hline
\end{tabular}

Source: compiled by the author.

The findings of the study are presented under the each research question.

Research Question 1: What are the factors that affect the interpersonal relationships between the counsellors and the owner managers in co-production?

The findings reveal that expertise of the counsellor, similarities, intensity of contacts, power distance and debt collection role of the counsellor affect the relationship between the counsellor and the owner manager.

Counsellor expertise was found as a factor that enhances the interpersonal relationship between the counsellor and the owner manager. This was evident from the following excerpt.

The owner manager of MFI-1 expressed that.

"Our counsellor is very knowledgeable and experienced. So we always want to work with him to get his advice."

The owner manager wanted to work with the counsellors as they could trust them due to the expertise of the counsellors.

The findings also show that interpersonal relationships could be improved if the parties demonstrate similar characteristics. The study reveals that similarity in the form of dress code, social interaction, and attitudes help enhance interpersonal relationships between parties.

The counsellors of MFI- 1 and MFI-3 mentioned that they wear clothes similar to the clients (i.e. dress code).

The counsellor of MFI-1 stated that

"When we go to the field to meet clients we never wear ties and coats, as that will distance ourselves from them."

The dress code of the counsellor improves the satisfaction of the owner managers as they think that the counsellor's lifestyle is similar to theirs. This has resulted in improved relationships between the parties.

The findings reveal that social interaction between the parties enhances the interpersonal relationships as it improves the satisfaction.

Social interaction between the counsellors and owner managers improves the relationships, which could result in satisfaction between the parties.

The counsellor of MFI-3 declared that;

"We always attend clients' weddings and other events. When we go to the field and meet the client, we always greet them and ask how their family is doing. So a client is delighted and in this way we keep in touch with them."

The owner manager of MFI-3 stated that;

"Our counsellor is very friendly with us. He is like a family friend; he even attends our family functions."

The findings show that the counsellors looked at owner managers' problems from their perspectives (similar attitudes). This has improved the relationships due to owner managers' satisfaction towards the counsellor. The following are two quotations to support this.

The counsellor of MFI-2 declared that; 
"Our clients are low income and uneducated people. So we have to put ourselves in the client's shoes when dealing with them. Then the clients feel comfortable and say everything. In this way we can establish a relationship with the client."

The owner manager of MFI-6 supported the counsellors' opinion, saying;

"We like it if our counsellor looks at our problems from our point of view."

The findings further reveal that intensity of contact between the counsellors and owner managers improve the relationships. Accordingly, counsellors of MFI-1, MFI-2, MFI-4 and MFI-5 mentioned that they always visit owner managers and keep in touch with them.

The counsellor of MFI-1 stated that;

"When you visit the client a few times the client becomes closer to you, resulting in a better relationship. This relationship helps me to have a better counselling session."

However, it was noticed that sometimes the counsellors cannot visit the owner managers frequently due to their high work load.

The counsellor of MFI-3 indicated that;

"Visiting the client regularly is very important. But unlike in the past, today we do not have time to visit the client regularly due to the high workload. I have to handle 300 clients."

To strengthen the interpersonal relationships the owner managers also need to put an effort by contacting counsellors regularly. This was substantiated by the following excerpts.

The counsellor of MFI-3 said that;

"My good clients are always in touch with me. When they come to the bank branch to deposit money or any other thing, they come and say hi to me."

Similarly, owner manager of MFI-3 stated that;

"I am always in touch with my counsellors. I call them regularly and if I go to the bank, I will definitely see them."

It was also evidenced from MFI-1, MFI-2, MFI-3 and MFI-4 that the owner managers maintain a submissive relationship with the counsellors due to the power distance. This can be expected as there is a higher power distance between the superiors and subordinates.

The counsellor of MFI-3 indicated that;

"When we go to the field the clients call us as "Mahatthaya" (Sir). This shows they are respectful to us and as a result they always want to listen to us."

However, this submissive relationship was not evident from MFI-5 and MFI-6 because the counsellors attached to these MFIs are clients themselves (i.e. MFI-5 and MFI-6 recruit their clients as counsellors) and hence, the owner managers/clients do not perceive them as superior to them.

Factors that weaken the relationship - The findings show that the debt collection role of the counsellor could damage the interpersonal relationships between the parties. The following are quotations to substantiate this.

The counsellor of MFI-4 said that;

"Due to recovery work, we sometimes cannot provide business counselling to default clients as we have to chase up defaulters. Furthermore, we have to be harsh on clients at times. When we visit default clients sometimes they hide. This damages the relationship between the counsellor and the client."

The owner manager of MFI-4 stated that;

"Field officers (counsellors) help us with obtaining loans and give us knowledge. But sometimes when they chase up defaulters, visiting them in the night or early in the morning, it could be scary." 
SocioEconomic Challenges, Volume 4, Issue 2, 2020

ISSN (print) - 2520-6621, ISSN (online) - 2520-6214

The findings reveal that due to the debt collection role played by the counsellors, they will stand to lose the trust with the defaulters and thereby, the defaulters will lose the satisfaction towards the counsellors resulting in weaker interpersonal relationships.

Question 02. How do interpersonal relationships enhance the co-production in BDS?

The improved interpersonal relationships have led to better co-production resulting in personal and communal favours (i.e. co-production outcomes as well as in the improvement of information provision of the owner managers. The information provided by the owner managers are vital for better counselling intervention.

The following two evidences show how co-production through interpersonal relationships enhance personal favours.

The counsellor of MFI-3 said that;

"When I went to my grandfather's home when he passed away, one of clients had come before me and repaired the road, which was not in a good condition. So we maintain a very good relationship with the clients."

The owner manager of MFI-3 stated that;

"Our counsellor also helps us for our personal things. For example, last week he advised me on my son's education."

Given below is an example to illustrate how enhanced relationships bring about communal favours which is related to co-production outcomes for parties (e.g. better sales and profits for owner managers).

The counsellor of MFI-3 expressed that;

"I consider someone as a good client if he follows my advice, cooperates with me, pays the loan instalments regularly and conducts his business well. I maintain a good relationship with those good clients more and I help them more. For example, recently I came across a good plot of pineapple land to be sold. So I gave this lead to one of my good clients who is in the pineapple business. Also, when I have marketing linkages, first I give them to clients who maintain good relationships with me."

The findings also reveal that relationships enhance the owner managers' provision of information to counsellor which is significant in co-production. The following is a quotation to support this.

The counsellor of MFI-5 expressed that;

"Clients provide information to us if there is a good relationship and a bond. If the client is close, then he reveals everything. So it is up to the officer to get close to the client."

When the relationships are strong between parties first they exchange personal favours and then they exchange communal favours (i.e. Co-production outcomes). Further, the owner managers provide information to the counsellors when there is a good interpersonal relationship present.

Question 03. How do organisational factors affect interpersonal relationships between the counsellors and the owner managers and thus, the co-production in BDS?

As explained above, the power distance was affected by the type of MFI that determines the counsellor recruitment strategy. There is a low power distance experienced in MFI-5 and MFI-6 as these MFIs have counsellors selected from the clients.

As revealed above, the type of linkage affects the interpersonal relationship between the parties. For example, the counsellors of MFI-1 and MFI- 2 do not have the debt collection roles as the attached MFI belongs to the type classified as parallel linkage. Thus, they could maintain better relationships with the owner managers compared to MFIs with unified linkages in which the counsellors have to partake in the debt collection role as well.

\section{Conclusions, Discussion and Implications}

The findings reveal that there are number of factors such as counsellor expertise, similarity, intensity of contact, and power distance that affect the interpersonal relationships. It was also revealed that the debt 
collection role of the counsellors weaken the relationship between the parties. The findings further show that enhanced relationships between the counsellors and the owner managers improve the co-production in BDS. Thus, parties exchange personal favours first and then move on to communal favours that are the goals of the co-production. Moreover, enhanced relationships encourage owner managers to provide information to the counsellors that is key to a better co-production. The findings also show that organisational factors such as type of MFI and type of linkage affect the interpersonal relationships.

The findings relating to the factors affecting interpersonal relationships are in line with the literature (Doney and Joseph, 1997; Bove and Johonson, 2000; Crosby et al., 1990; Byrne, 1969; Tan, 1981). The literature related to marketing shows that service/sales personnel with expertise are trusted by the clients and thus, they maintain better relationships with service personnel (Busch and Wilson, 1976; Taylor and Woodside, 1981; Crosby et al., 1990). The literature also points out that similarity between people in term of dress code, social interaction and attitudes lead to better relationships between parties and this results in superior client satisfaction (Tan 1981; Byrne 1969). The literature further shows that the intensity of contact between the service personnel and client improves the relationship (Bove and Johonson, 2000). At the same time, frequent contact results in trust, satisfaction and commitment between parties strengthening the relationships. The literature also shows that frequent the interaction between the parties leads to stronger affection or liking for one another, giving them mutual rewards (Doney and Joseph, 1997; Crosby et al., 1990). Power relations between counsellor and client also factor in the development of interpersonal relationships, as with a high level of power distance people tend to accept the hierarchical order. Therein, subordinates are expected to do what they are told by the superiors (Hofstede, 2014; Hofstede and Hofstede, 2005). Countries such as Sri Lanka which have a higher power distance are found with individuals who are more submissive to the superiors.

The existent literature supports that co-production through the enhanced interpersonal relationships results in personal favours and communal favours. The study made by Guo and $\mathrm{Ng}$ (2011) on equipment-based services shows that interpersonal relationships help achieve co-production outcomes. At the beginning, interpersonal relationships help achieve personal favours and once the relationship is established, then parties achieve communal favours. The literature also supports that information provision is an outcome of enhanced interpersonal relationships. Information provision has also been identified as an important factor in coproduction. (Hsieh et al., 2004; Bettencourt et al., 2002; Bitner et al., 1997). The study done by Hawke and Heffernan's (2006) on interpersonal relationships in the banking industry, found that the clients open up and communicate better (i.e. information provision) with the lender due to the enhanced relationships. The finding on negative impact of the counsellor's debt collection role on the interpersonal relationship is reinforced by Rob et al. 's (2007) study on loan officers and loan delinquency. This study shows that default clients are scared of meeting the loan officers and thereby damages the relationship between the client and the loan officer. The findings relating to organisational factors affecting interpersonal relationships is a new finding not supported by the existent literature.

Given the importance of interpersonal relationships in co-production that help achieve the objectives of parties, MFIs must take actions to improve interpersonal relationships between the counsellors and the owner managers. MFIs can hire counsellors with expertise and develop their expertise more by giving them training. MFIs must allow the counsellors to interact with the owner managers frequently, request the counsellors to dress as the owner managers, encourage social interaction and train them to look at the owner managers' problems from their point of view to improve interpersonal relationships. Further, MFIs should try to minimize the counsellor's role in debt collection as it is detrimental to strong interpersonal relationships.

This study contributes to the microfinance, co-production and marketing literature. Based on the findings of the study future researches can be done in different contexts and quantitative studies could be undertaken.

\section{References}

1. Abeysekera, R. (2016). Enhancing entrepreneurship in Sri Lanka: the provision of business development services (BDS) by microfinance institutions to support the self-sufficiency of microenterprises (Doctoral dissertation, Bournemouth University). http://eprints.bournemouth.ac.uk/24721/ (accessed May 05, 2020).

2. ADB (1997). Microenterprise development: Not by credit alone. Manila: Asian Development Bank. https://www.findevgateway.org/library/microentreprise-development-not-credit-alone. May12, 2020). 
3. Bettencourt, L. A., Ostrom, A. L., Brown, S. W. and Roundtree, R. I. (2002). Client co-production in knowledge-intensive business services. California Management Review, 44 (4), 100-128. https://doi.org/10.2307\%2F41166145

4. Bitner, M. J., Faranda, W. T., Hubbert, A. R. and Zeithaml, V. A. (1997). Customer contributions and roles in service delivery. International Journal of Service Industry Management, 8 (3), 193-205. https://doi.org/10.1108/09564239710185398.

5. Bove, L. L., and Johnson, L. W. (2000). A customer-service worker relationship model. International Journal of Service Industry Management, 11(5), 491-511. https://doi.org/10.1108/09564230010360191.

6. Busch. P. and Wilson, D. T. (1976). An experimental analysis of a salesman's expert and referent based on social power in the buyer-seller dyad. Journal of marketing research. 13 (February), 3-11. https://doi.org/10.1177\%2F002224377601300102.

7. Byrne, D (1969). Attitudes and attraction. In: Berkowitz L, ed. Advances in experimental social psychology, vol. 4. New York: Academic Press, 36- 86. http://doi.apa.org/psycinfo/1971-02285-001

8. Canadian APEC, IBIZ (2015). Asia Pacific Economic Cooperation, International network of institutes of small business counsellors. http://www.xlin.com/business-counselling.html (Accessed 04 May 2020).

9. CGAP (2011). Advancing financial access to world poor [online]. Washington: Consultative group to assist the poor. http://www.cgap.org/p/site/c/about/ (Accessed 04 May, 2020).

10. Chrisman, J. J., and McMullan, W. E. (2000). A Preliminary assessment of outsider assistance as a knowledge resource: the longer-term impact of new venture counseling. Entrepreneurship theory and practice, 24 (3), 37-53. https://doi.org/10.1177\%2F104225870002400303.

11. Crosby, L. A., and Stephens, N. (1987). Effects of relationship marketing on satisfaction, retention, and prices in the life insurance industry. Journal of marketing research, 404-411. https://doi.org/10.1177\%2F002224378702400408.

12. Crosby, L. A., Evans, K. R. and Cowles, D. (1990). Relationship quality in services selling: An interpersonal influence perspective. Journal of marketing, 54 (July), 68-81. https://doi.org/10.1177\%2F002224299005400306.

13. Cumming, D. J. and Fischer, E. (2012). Publicly funded business advisory services and entrepreneurial outcomes. Research Policy, 41 (2), 467-481. https://doi.org/10.1016/j.respol.2011.09.004.

14. Cull, R., Demirgüç-Kunt, A. and Morduch, J. (2018). The microfinance business model: Enduring subsidy and modest profit. The World Bank Economic Review, 32(2), 221-244. https://doi.org/10.1093/wber/lhx030.

15. Doney. P. M. and Joseph P. C. (1997). An examination or the nature of trust in buyer-seller relationships. Journal of marketing. 61 (April). 35-51. https://doi.org/10.1177\%2F002224299706100203.

16. Dunford, C. (2001). Building better lives: Sustainable linkage of microcredit and education in health, family planning and HIV/AIDS prevention for the poorest entrepreneurs. Washington DC: Freedom from Hunger, commissioned by Microcredit Summit Campaign. https://scholarsarchive.byu.edu/esr/vol3/iss2/2/( Accessed 10 May, 2020).

17. Easterly, W. (2006). The white man's burden: Why the West's efforts to aid the rest have done so much ill and so little good. New York: Penguin Press. https://www.nwmissouri.edu/academics/pdf/rbr/2007.pdf\#page=104 ( Accessed 10 May, 2020)

18. Eisenhardt, K. M. (1989). Building theories from case-study research. Academy of management review, 14 (4), 532-550. https://doi.org/10.1016/j.jbusres.2010.08.014.

19. Etgar, M. (2008). A descriptive model of the consumer co-production process. Journal of the academy of marketing science, 36 (1), 97-108. https://doi.org/10.1007/s11747-007-0061-1.

20. Fisher, T. and Sriram, M. S. (2002). Beyond micro-credit: Putting development back into micro-finance. New Delhi: Vistar Publications. https://policy-practice.oxfam.org.uk/publications/beyond-micro-creditputting-development-back-into-micro-finance-122837 ( Accessed 11 May, 2020).

21. Galema, R., Lensink, R. and Mersland, R. (2012). Do powerful CEOs determine microfinance performance? Journal of management studies, 49 (4), 718-742. https://doi.org/10.1111/j.14676486.2012.01046.x.

22. GTZ ProMiS (2010). Micro Finance Industry Report. Sri Lanka: GTZ ProMiS and The Banking With the Poor Network. https://www.findevgateway.org/sites/default/files/publications/files/mfg-en-papermicrofinance-industry-report-sri-lanka-2010.pdf ( Accessed 04 May, 2020)

23. Gulli, H. and Berger, M. (1999). Microfinance and poverty reduction - evidence from Latin America. Small enterprise development, $10 \quad$ (3), $16-28 . \quad$ chromeextension://ohfgljdgelakfkefopgklcohadegdpjf/https://www.adb.org/sites/default/files/publication/15717 
4/adbi-rp63.pdf

24. Guo, L. and Ng, I. (2011). The co-production of equipment-based services: An interpersonal approach. European management journal, 29 (1), 43-50. https://doi.org/10.1016/j.emj.2010.08.005.

25. Hawke, A. and Heffernan, T. (2006). Interpersonal liking in lender-customer relationships in the Australian banking sector. International Journal of Bank Marketing, 24 (2/3), 140-157. https://doi.org/10.1108/02652320610659003.

26. Hofstede, G. and Hofstede, G. J. (2005). Cultures and organizations. Software of the mind. Intercultural cooperation and its importance for survival. 2nd edition. New York: McGraw-Hill. chromeextension://ohfgljdgelakfkefopgklcohadegdpjf/https://globalsociology.ucoz.ru/_ld/0/2_CulturesandOrga.pdf

27. Hofstede, G. (2014). What about Sri Lanka? [Online]. Helsinki: The Hofstede centre. http://geerthofstede.com/sri_lanka.html (Accessed 13 May 2020).

28. Hsieh, A. T., Yen, C. H. and Chin, K. C. (2004). Participative customers as partial employees and service provider workload. International journal of service industry management, 15 (2), 187-199. https://doi.org/10.1108/09564230410532501.

29. Hulme, D and Mosley, P. (1996). Finance against poverty. Routledge: London. https://www.amazon.com/Finance-Against-Poverty-Hulme-David/dp/0415124298 ( Accessed 07 May, 2020).

30. Jansson, T., Rosales, R. and Westley, G. (2004). Principles and Practices for Regulating and Supervising Microfinance. Washington, DC: Inter-American Development Bank. https://publications.iadb.org/en/publication/11768/principles-and-practices-regulating-and-supervisingmicrofinance (Accessed 07 May, 2020).

31. Johnson, D. J., 1991. Counselling business startups and owner managers of small firms: a psychological study, Part 1. Journal of Workplace Learning, 3 (5), 10-14. https://doi.org/10.1108/EUM0000000002866.

32. Johnson, S. and Rogaly, B. (1997). Microfinance and poverty reduction. Oxford: Oxfam.

33. Khavul, S. (2010). Microfinance: Creating Opportunities for the Poor? Academy of management perspectives, 24 (3), 58-72. https://doi.org/10.5465/amp.24.3.58.

34. Klinger, B., and Schündeln, M. (2011). Can entrepreneurial activity be taught? Quasi-experimental evidence from Central America. World development, 39 (9), 1592-1610. https://doi.org/10.1016/j.worlddev.2011.04.021.

35. Lean, J., Down, S. and Sadler-Smith, E. (1999). The nature of the client-personal business advisor relationship within Business Link. Journal of small business and enterprise development, 6(1), 80-88. https://doi.org/10.1108/EUM0000000006666.

36. Maes, J. and Foose, L. (2006). Microfinance and non-financial services for the very poor: digging deeper to find keys to success. Washington, DC: Seep Network - Poverty Outreach Working Group. chromeextension://ohfgljdgelakfkefopgklcohadegdpjf/https://www.findevgateway.org/sites/default/files/publica $\underline{\text { tions/files/mfg-en-paper-microfinance-and-non-financial-services-for-very-poor-people-digging-deeper- }}$ to-find-keys-to-success-oct-2006.pdf

37. Meuter, M. L. and Bitner, M. J. (1998). Self-service technologies: Extending service frameworks and identifying issues for research. In: Grewal, D. and Pechmann, C. (eds). AMA Winter Educators' Conference. Chicago: American Marketing Association. https://search.proquest.com/openview/f4c4769d201d67ae277eb95b713b55ec/1?pqorigsite $=$ gscholar \&cbl $=35292$ (Accessed 07 May, 2020).

38. Mosley, P. and Hulme, D. (1998). Microenterprise finance: is there a conflict between growth and poverty alleviation? World development, 26 (5), 783-790. https://doi.org/10.1016/S0305-750X(98)00021-7.

39. Mulamula, J. (2018). Business Development Service and the Performance of Informal Businesses in Uganda: The Case of Pride Microfinance (Doctoral dissertation, Makerere University). http://dspace.mak.ac.ug/handle/10570/6755 ( Accessed 07 May, 2020).

40. NEDA (2013). Micro enterprise policy paper [Online]. Sri Lanka: National Enterprise Development Authority. https://www.neda.gov.lk/web/index.php?lang=en ( Accessed 07 May, 2020).

41. Parks, R. B., Baker, P. C., Kiser, L., Oakerson, R., Ostrom, E., Ostrom, V., Percy, S. L., Vandivort, M. B., Whitaker, G. P. and Wilson, R. (1981). Consumers as coproducers of public services: some economic and institutional considerations. Policy studies journal, 9 (7), 1001-1011. https://doi.org/10.1111/j.15410072.1981.tb01208.x.

42. Prahalad, C.K. and Ramaswamy, V. (2000). Co-opting customer competence. Harvard business review, 78(1), 79-87. https://hbr.org/2000/01/co-opting-customer-competence (Accessed $07 \mathrm{May}, 2020$ ). 
43. Prahalad, C.K. and Ramaswamy, V. (2002). The co-creation connection', Strategy and business, 27 (2), 51-60. https://strain.typepad.com/unplugged/files/booz_allen_experience_management_prahalad.pdf (Accessed 07 May, 2020)

44. Prahalad, C.K. and Ramaswamy, V. (2004a). Co-creation experiences: the next practice in value creation. Journal of interactive marketing, 18 (3), 5-14. https://doi.org/10.1002/dir.20015

45. Prahalad, C.K., and Ramaswamy, V. (2004b). The future of competition: co-creating unique value with customers. Boston: Harvard Business School. https://store.hbr.org/product/the-future-of-competition-cocreating-unique-value-with-customers/9535

46. Rice, M. P. (2002). Co-production of business assistance in business incubators - An exploratory study. Journal of business venturing, 17 (2), 163-187. https://doi.org/10.1016/S0883-9026(00)00055-0

47. Rob, D., John, R. and Juliana, S. (2007). Loan officers and loan 'delinquency' in Microfinance: a Zambian case. Accounting forum, 31 (1), 47-71. https://doi.org/10.1016/j.accfor.2006.11.005

48. Rogaly, B. (1996). Micro-finance Evangelism, 'Destitute Women', and the hard selling of a new antipoverty formula. Development in practice, 6 (2), 100-112. https://doi.org/10.1080/0961452961000157654

49. Schayek, K. and Dvir, D. (2009). Measuring the effect of public assistance programs on small businesses' performance. Journal of general management, $35 \quad$ (2), 3-20 https://doi.org/10.1177\%2F030630700903500202.

50. Sievers, M., and Vandenberg, P. (2007). Synergies through linkages: who benefits from linking microfinance and business development services? World development, 35 (8), 1341-1358. https://doi.org/10.1016/j.worlddev.2007.04.002.

51. Swan, J. E., Trawick, I. F. and Silva, D. W. (1985). How industrial salespeople gain customer trust. Industrial marketing management, 14(3), 203-211. https://doi.org/10.1016/0019-8501(85)90039-2.

52. Tan, A. S. (1981). Mass Communication Theories and Research. Columbus, Ohio: Grid Publishing, Inc. http://www.worldcat.org/title/mass-communication-theories-and-research/oclc/6195727

53. Taylor, J. L. and Woodside, A. G. (1981). Exchange behaviour among salesman and customers in natural settings. In: Reingen, P. H. and Woodside, A. G. (eds). Buyer-Seller Interactions: Empirical Research and Normative Issues. Chicago: American Marketing Association. https://journals.sagepub.com/doi/10.1177/002224299005400306

54. Tilakaratne, G., Galappattige, A. and Perera R. (2009). Promoting empowerment through microfinance in Sri Lanka, economic and political empowerment of the poor-Sri Lanka. Sri Lanka: Centre for policy dialogue, South Asia Centre for policy studies. http://www.centreofexcellence.net/index.php/JBM/article/view/286

55. Tilakaratne, G., Wickramsinghe, U. and Thusitha, K. (2005). Micro finance in Sri Lanka: a household level analysis of outreach and impact on poverty. Sri Lanka: Institute of Policy Studies of Sri Lanka. http://www.pep-net.org/sites/pep-net.org/files/typo3doc/pdf/files_events/4th_colombo/Ganga.pdf (Accessed 07 May, 2020).

56. Vargo S. L. and Lusch R. F. (2004). Evolving to a new dominant logic for marketing. Journal of marketing, 68 (1), 1-17. https://doi.org/10.1509\%2Fjmkg.68.1.1.24036.

57. Vargo S. L. and Lusch R. F. (2006). Evolving to a new dominant logic for marketing. In: Lusch R. F., and Vargo S. L. (eds). The service dominant logic of marketing: dialog, debate and directions, New York: Routledge. https://doi.org/10.1177\%2F009207030603400225

58. Weaver, B. (2019). Co-production, governance and practice: The dynamics and effects of User Voice Prison Councils. Social Policy \& Administration, 53(2), 249-264. https://doi.org/10.1111/spol.12442.

59. World Bank, 2014. Poverty Review [Online]. Washington DC: World Bank. http://www.worldbank.org/en/topic/poverty/overview [accessed 10 May, 2020].

60. Wright, G. A. (1999). Examining the impact of microfinance services - increasing income or reducing poverty? Small enterprise development, $10 \quad 38-47$. http://www.arabic.microfinancegateway.org/sites/default/files/mfg-en-paper-examining-the-impact-ofmicrofinance-services-increasing-income-or-reducing-poverty-2000.pdf

61. Yin, R. K. (2009). Case-study research: Design and methods 4th edition ed. London: Sage. DOI: https://doi.org/10.33524/cjar.v14i1.73 